\title{
Maize Grain Yield Limiting Nutrients in North West Ethiopia: Pawe District
}

\author{
Getachaw Yilma* Mamo Bekele \\ Ethiopian institute of Agricultural Research, Pawe Agricultural Research Center
}

\begin{abstract}
Soil fertility is the central axis of agricultural productivity. Different approaches are being exercised and applying appropriate rate of chemical fertilizer is the one. A study was conducted in Pawe district to evaluate the effects of $\mathrm{N}, \mathrm{P}, \mathrm{K}$ and $\mathrm{S}$ fertilizers on maize grain yield for two consecutive years. Including negative control $23,46,69,92 \mathrm{~kg} / \mathrm{ha}$ of $\mathrm{N}, 10,20$ and $30 \mathrm{~kg} / \mathrm{ha}$ of P with $92 \mathrm{Kg}$ of N, 10, $20 \& 30 \mathrm{~kg} / \mathrm{ha}$ of K and 2.5,5,7 kg of S were also combined to evaluate their effect of maize grain yield. Maximum grain yield was recorded from treatments with $92 \mathrm{~N} 20 \mathrm{P}$ and $92 \mathrm{~N} 10 \mathrm{P}$, but the economic analysis indicates that maximum marginal rate of return is higher at $69 \mathrm{~N}$ while maximum net benefit is at 92N10P.
\end{abstract}

Keywords: Soil Fertility, Fertilizer,Net Benefit, Marginal Rate of Return.

DOI: $10.7176 / \mathrm{JBAH} / 11-17-01$

Publication date:September $30^{\text {th }} 2021$

\section{Introduction}

Enhancing agricultural productivity is one of the central challenges to achieving food security and poverty reduction in Ethiopia (Abdulkadir et al., 2017) . Land degradation in the form of soil erosion and soil nutrient depletion are critical challenges to agricultural production and economic growth in Ethiopia. On farm lands, in particular, there is a continuous decline in soil quality resulting from reduced fallows and the sub-optimal use of input (Lemenih et al., 2005).

Maize (Zea mays L.) is the most widely cultivated cereal crop in terms of area coverage (16\%) and production (26\%) with about 6.5 million t of production in Ethiopia (CSA, 2011). It is also one of the most important staple crops in Pawe. Despite the release of several high yielding maize (Zea mays L.) varieties to smallholder farmers and its high adoption rate, maize production levels in sub-Saharan Africa remain low (Kalonga, 2002). Soil fertility degradation is one of the major challenges. Therefore it is required an appropriate additions of nutrient to soil towards achieving the goal of sustainable maize productivity and profitability Detchinli and Sogbedji (2015). Improving soil fertility and use of improved maize varieties can significantly inhances water productivity (Erkossa et.al 2011).

Nitrogen $(\mathrm{N})$ and phosphorus $(\mathrm{P})$ are the most important nutrients limiting crop production in the dry land areas of Ethiopia, (Asnakew 1991). But currently the major fertilizer used by farmers are blended fertilizers which contains N, P, S and other micro nutrients like B and Zn based on ATA's soil fertility map recommendation. But the rate and composition of each fertilizer is still unknown.

The objective of this study was so to identify the required nutrient type and to determine the rate of each nutrient in Pawe area.

\section{Material and Methods}

The activity was done on nitisol of Pawe district in North West Ethiopia on Maize (HB 540). Pawe is located in Metekel Zone of Benishangul Gumuze region. The soil on which the trial conducted was nitisol. The trial was done on two subsequent rainy seasons of years 2015 and 2016. N fertilizer was mainly supplied by UREA fertilizer while was from TSP (triple super phosphate). Potassium was obtained from potassium chloride. For sulfur application we used NPS fertilizer by adjusting N and P with Urea and TSP respectively. Urea was applied three times, at planting, at knee height and at flowering, while P, K and S sources of fertilizer were applied once at the time of planting.

Table 1. Treatments

\begin{tabular}{llll} 
Treatments & Nutrient level & treatments & Nutrient level \\
\hline 1 & Control $(0,0,0)$ & 9 & $69 \mathrm{~N} 20 \mathrm{P}$ \\
2 & $23 \mathrm{~N}$ & 10 & $92 \mathrm{~N} 20 \mathrm{P}$ \\
3 & $46 \mathrm{~N}$ & 11 & $92 \mathrm{~N} 10 \mathrm{P}$ \\
4 & $69 \mathrm{~N}$ & 12 & $92 \mathrm{~N} 20 \mathrm{P} 20 \mathrm{~K}$ \\
5 & $92 \mathrm{~N}$ & 13 & $92 \mathrm{~N} 30 \mathrm{P}$ \\
6 & $20 \mathrm{P}$ & 14 & $92 \mathrm{~N} 20 \mathrm{P} 10 \mathrm{~K} 2.5 \mathrm{~S}$ \\
7 & $23 \mathrm{~N} 20 \mathrm{P}$ & 15 & $92 \mathrm{~N} 20 \mathrm{P} 20 \mathrm{~K} 5 \mathrm{~S}$ \\
8 & $46 \mathrm{~N} 20 \mathrm{P}$ & 16 & $92 \mathrm{~N} 20 \mathrm{P} 30 \mathrm{~K} 7.5 \mathrm{~S}$
\end{tabular}


3. Result Disscusion.

Table 2 The two years combined anova table of maize grain yield

\begin{tabular}{|c|c|c|c|}
\hline Nutrient level $\mathrm{kg} \mathrm{ha}^{-1}$ & Grain Yield t. ha ${ }^{-1}$ & Nutrient level $\mathrm{kg} \mathrm{ha}^{-1}$ & Grain Yield t. ha ${ }^{-1}$ \\
\hline Control & $2.5337^{\mathrm{g}}$ & $69 \mathrm{~N} 20 \mathrm{P}$ & $4.6938^{\mathrm{abcd}}$ \\
\hline $23 \mathrm{~N}$ & $3.5082^{\mathrm{efg}}$ & 92N20P & $5.7225^{\mathrm{a}}$ \\
\hline $46 \mathrm{~N}$ & $3.5185^{\mathrm{efg}}$ & 92N10P & $5.5805^{a}$ \\
\hline $69 \mathrm{~N}$ & $4.428^{\text {bcde }}$ & $92 \mathrm{~N} 20 \mathrm{P} 20 \mathrm{~K}$ & $5.195^{\mathrm{abc}}$ \\
\hline $92 \mathrm{~N}$ & $4.060^{\text {cdef }}$ & $92 \mathrm{~N} 30 \mathrm{P}$ & $5.2958^{\mathrm{ab}}$ \\
\hline $20 \mathrm{P}$ & $3.0352^{\mathrm{gf}}$ & $92 \mathrm{~N} 20 \mathrm{P} 10 \mathrm{~K} 2.5 \mathrm{~S}$ & $5.3182^{\mathrm{ab}}$ \\
\hline 23N20P & $3.8917^{\text {def }}$ & $92 \mathrm{~N} 20 \mathrm{P} 20 \mathrm{~K} 5 \mathrm{~S}$ & $4.6368^{\mathrm{abcd}}$ \\
\hline $46 \mathrm{~N} 20 \mathrm{P}$ & $4.1448^{\text {cdef }}$ & $92 \mathrm{~N} 20 \mathrm{P} 30 \mathrm{~K} 7.5 \mathrm{~S}$ & $5.3468^{\mathrm{ab}}$ \\
\hline LSD & & 1.1417 & \\
\hline $\mathrm{CV}(\%)$ & & 19.5 & \\
\hline Probability & & $\infty=0.05$ & \\
\hline
\end{tabular}

The overall two years data was passed to combined analysis and the result shows there is highly significant difference between treatments. Even if most treatments have significant difference from the control plot maximum grain yield was attained at $92 \mathrm{~N} 20 \mathrm{P}$ which is statistically the same to treatment with $92 \mathrm{~N} 10 \mathrm{P}$. The treatments with the application of Potassium \& Sulfur have no any yield advantage to non-treated treatments. This may be due to the presence of these nutrients in the soil. The result indicates that the main yield limiting factors are $\mathrm{N}$ and $\mathrm{P}$. application of maximum amount of $\mathrm{N}(92 \mathrm{~kg})$ gives the highest grain yield while the application of 10 and $20 \mathrm{P}$ doesn't have any significant yield difference. Therefore the application of 92N10P is the best treatment than the others to get maximum grain yield, because it minimizes the cost of $\mathrm{P}$ fertilizer by half than the treatment $92 \mathrm{~N} 20 \mathrm{P}$. in addition application of $30 \mathrm{P}$ causes yield reduction.

As Birhan et al. (2017) reviewed different studies shows different responses of maize to various fertilizer rates in different agro-ecologies; this is because the inherent fertility of soil varies from place to place.

The economic analysis result based on the current costs of fertilizer and grain shows the maximum net benefit was attained at the treatment $92 \mathrm{~N} 10 \mathrm{P}$ which was significantly higher from others and recommended. But the marginal rate of return indicates the treatment with $69 \mathrm{~N}$ has the maximum marginal rate of return (MRR) which means higher benefit with lower total cost was obtained at $69 \mathrm{~N}$.

Table 3: The economic analysis result

\begin{tabular}{|c|c|c|c|c|c|c|c|}
\hline Fertilizer Rate & Grain Yield & $10 \% \mathrm{AGY}$ & GFB & TC V & N Benefit & MRR-ratio & MRR $\%$ \\
\hline Control & 2533.745 & 2280.371 & 11401.85 & 0 & 11401.85 & & \\
\hline $23 \mathrm{~N}$ & 3508.236 & 3157.413 & 15787.06 & 700 & 15087.06 & 5.264585 & 526.4585 \\
\hline $20 \mathrm{P}$ & 3035.312 & 2731.78 & 13658.9 & 1700 & 11958.9 & $\mathrm{D}$ & \\
\hline $46 \mathrm{~N}$ & 3518.425 & 3166.583 & 15832.91 & 2100 & 13732.91 & $\mathrm{D}$ & \\
\hline 23N20P & 3891.846 & 3502.661 & 17513.31 & 2400 & 15113.31 & 0.015437 & 1.543674 \\
\hline $69 \mathrm{~N}$ & 4427.948 & 3985.154 & 19925.77 & 2800 & 17125.77 & 5.031153 & 503.1153 \\
\hline $46 \mathrm{~N} 20 \mathrm{P}$ & 4145.003 & 3730.502 & 18652.51 & 3800 & 14852.51 & $\mathrm{D}$ & \\
\hline 69N20P & 4694.017 & 4224.615 & 21123.07 & 4500 & 16623.07 & $\mathrm{D}$ & \\
\hline $92 \mathrm{~N}$ & 4059.976 & 3653.979 & 18269.89 & 5356.522 & 12913.37 & $\mathrm{D}$ & \\
\hline $92 \mathrm{~N} 10 \mathrm{P}$ & 5580.505 & 5022.455 & 25112.27 & 6206.522 & 18905.75 & 0.522522 & 52.25223 \\
\hline $92 N 20 P$ & 5722.606 & 5150.345 & 25751.73 & 7056.522 & 18695.2 & $\mathrm{D}$ & \\
\hline $92 \mathrm{~N} 30 \mathrm{P}$ & 5295.86 & 4766.274 & 23831.37 & 7906.522 & 15924.85 & D & \\
\hline
\end{tabular}

\section{Conclusion}

The study indicates that application of $92 \mathrm{~kg}^{\text {-ha }}$ nitrogen source with the availability of $10 \mathrm{~kg}^{\text {-ha }}$ of phosphorus can give maximum grain yield with economic advantages over the treatment 92N20P and application of other nutrients like sulfur and potassium. Therefore it is better to follow soil test based approach for the application of nutrients other than nitrogen and phosphorus, because the application of excess potassium and sulfur may cause soil toxicity.

5. I declared that there is no conflict of interest between authors on this paper.

\section{References}

Abdulkadir, B., Kassa, S., Desalegn, T., Tadesse, K., Haileselassie, M., Fana, G., ... \& Tibebe, D. (2017). Crop response to fertilizer application in Ethiopia: a review. Crop Response to Fertilizer Rapplication. CIAT- 
International Centre for Tropical Agriculture, Addis Ababa..

Abera, T., Abera, D., Abera, Y., Gurmu, G., \& Shimbir, T. Soil Fertility Management in Ethiopia: Research Findings, Challenges, Opportunities and Prospects. Agricultural Research for Ethiopian Renaissance.

Birru, A. (1979). Agricultural field experiment management manual part III. IAR (Institute of Agricultural Research). Addis Ababa, Ethiopia, 35-42..

Boughton, D., Crawford, E., Krause, M., \& Henry de Frahan, B. (1990). Economic analysis of on-farm trials: a review of approaches and implications for research program design (No. 1099-2019-2208).

Central Statistical Agency (CSA). (2011). Agricultural sample survey: Report on area and production of major crops.

Cimmyt, M., \& Cimmyt, M. (1988). From agronomic data to farmer recommendations: an economics training manual. CIMMYT..

Erkossa, T., Awulachew, S. B., \& Aster, D. (2011). Soil fertility effect on water productivity of maize in the upper Blue Nile basin, Ethiopia. Agricultural Sciences, 2(03), 238.

Kalonga, S. (2002). Long term food security implications of a top-down agricultural strategies in Malawi (Doctoral dissertation, Ph. D. Thesis. Surrey Institute of Global Economics Research, Worcester Park, UK, 45 pp. http://www. unu. edu/africa/papers/development/Stambuli1. pdf).

Lemenih, M., Karltun, E., \& Olsson, M. (2005). Soil organic matter dynamics after deforestation along a farm field chronosequence in southern highlands of Ethiopia. Agriculture, ecosystems \& environment, 109(1-2), 9-19. Detchinli, K. S., \& Sogbedji, J. M. (2015). Yield performance and economic return of maize as affected by nutrient management strategies on ferralsols in coastal western Africa. European Scientific Journal, 11(27).

Shehu, B., Merckx, R., Jibrin, J., \& Rurinda, J. (2018). Quantifying variability in maize yield response to nutrient applications in the Northern Nigerian Savann 